International Journal of Computer and Information System (IJCIS)

Peer Reviewed - International Journal

Vol : Vol. 03, Issue 01, January 2022

e-ISSN : 2745-9659

https://ijcis.net/index.php/ijcis/index

\title{
The Influence of Information Technology and SCM on Competitive Advantage to Improve MSMEs Performance
}

\author{
$1^{\text {st }}$ Andri Ikhwana, $2^{\text {rd }}$ Sasi Dianti \\ ${ }^{1,2}$ Teknik Industri Institut Teknologi Garut \\ Garut, Indonesia \\ 1 andri_ikhwana@itg.ac.id, ${ }^{2} 1703074 @$ itg.ac.id
}

\begin{abstract}
The increasing number of MSMEs has a role for the national and regional economies. However, this increasing has not totally been released from the obstacles obstructing business development, especially in Garut Regency. Lack of capital, high raw materials, and difficulty in marketing products are some of the obstacles faced by business actors in Garut Regency. Meanwhile, based on the results of the regional competitiveness index report in 2019, it is known that Garut Regency falls into the moderate category and business dynamics are the pillars with the lowest conditions. The contribution of MSMEs and the increasing number of business competition as well as the condition of MSMEs of Garut Regency is currently the reason that MSMEs deserve attention. This research aims to explain the interactions occurring between variables in this study by testing the influence of information technology and SCM on competitive advantage to improve organizational performance in MSMEs in Garut Regency. Data on this study was obtained from 109 MSME actors in Garut Regency through the results of the spread questionnaires. While the technique used to analyse the data is Pearson product-moment correlation analysis and regression using SPSS statistics. This research reveals that: 1) Information technology influences supply chain management, 2) Information technology influences competitive advantage, 3) Information technology influences competitive advantage, and 4) Competitive advantage influences organizational performance 4)Competitive advantage has a strong and unidirectional relationship and has a positive influence on the performance of MSMEs of Garut regency by $62.1 \%$.
\end{abstract}

Keywords: Information Technology, Supply Chain Management, Competitive Advantage, Organizational Performance, Linear Regression.

\section{INTRODUCTION}

Micro Small and Medium Enterprises (MSMEs) play an important role in the national and regional economies. According to the Ministry of Cooperatives and SMEs, Kominfo, and BPS in 2020, the workforce in Indonesia absorbed by MSMEs is $97.02 \%$ and the national gross domestic product contributed by MSMEs is $61.07 \%$. In addition, MSMEs act as business provision for low-income communities in carrying out economic activities [1]. The development of technology today brings certain changes in the business world, such as product innovation produced by MSMEs which is increasingly diverse and competition between business actors is getting higher [2]. The role of MSMEs is quite large and the condition of increasingly high business competition is the reason that MSMEs deserve attention.

Business competition is the success or failure condition of a company in carrying out its business activities, while competitive advantage is the ability of the organization or company in creating positions above its competitors. The higher the competitive advantage occurs, the better the organizational performance is obtained. To achieve the competitive excellence, organizations must strive to increase productivity, create innovations, increase efficiency, and accelerate and facilitate services to be able to compete, excel, and still maintain their business [2]. Supply chain management is an approach that can be used to establish cooperative relationships between suppliers, manufacturers, distributors, retailers, and customers, so that it is expected to create cheap, quality, and fast delivery products [3]. Through information technology, MSME actors can coordinate relationships in the supply chain, support sales and marketing, production and operations, and report the processes from work results. Slamet [4] in his research said that the strategy in developing MSMEs digitally is needed in the production process and market expansion so that it will have competitiveness in improving the company's performance [2].

Information technology plays an important role for businesses in maintaining their business, such as the role of digital in business in 2020. By 2020, all sectors will be declined, except digital sectors. The government appealed to all sectors including MSMEs to shift their business processes towards digital. Furthermore, digital utilization is a solution for MSME actors to maintain their business. In this case, the Ministry of Cooperatives and SMEs stated that MSMEs that can survive in 2020 are MSMEs that are already connected to online platforms. The following is the results of research conducted by Katadata Insight Center in July 2020 (Figure 1). MSME respondents as many as $34.6 \%$ claimed to have switched their business processes from offline to online marketing systems, which is considered as the way to maintain their business since digital utilization can be used for marketing processes, access for capital, as well as to support interaction with customers and support the production process in the current. The following is how MSMEs maintain their business in 2020 The graphic image of business maintenance can be seen in Figure 1 [5]: 
International Journal of Computer and Information System (IJCIS)

Peer Reviewed - International Journal

Vol : Vol. 03, Issue 01, January 2022

e-ISSN : 2745-9659

https://ijcis.net/index.php/ijcis/index

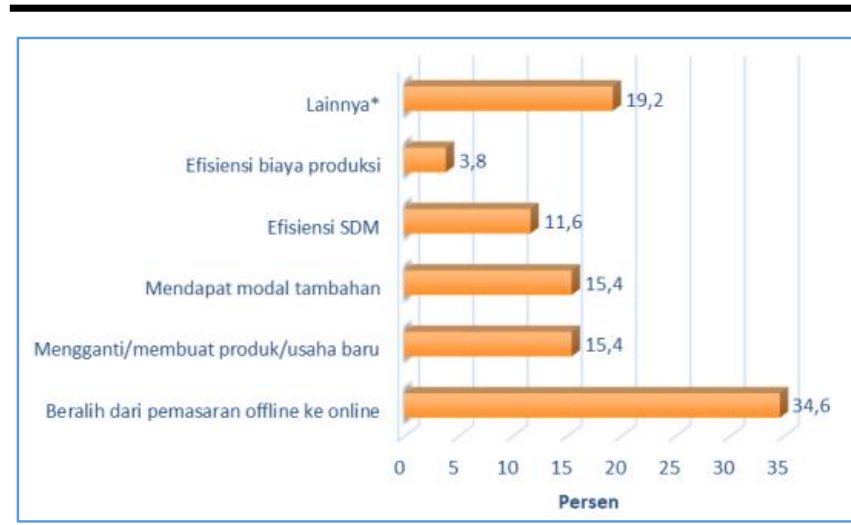

Figure 1. How MSMEs Maintain Business (Source: Katadata Insight Center (KIC))

According to the Garut Regency Cooperative and SME Office (2021), MSMEs in Garut Regency have several obstacles, including lack of capital, high raw materials, and difficulty in marketing products. While based on the results of research, several factors obstructing the competitiveness of MSMEs in East Priangan including MSMEs in Garut Regency are lack of capital, weak creativity and innovation, low quality of products and quality of human resources, high raw materials, the low purchasing power of the community, lack of collaboration of MSMEs with supporters, and limited government support for product marketing [6]. In addition, judging from the regional competitiveness index in 2019, the lowest conditions experienced by Garut Regency are the pillars of business dynamics. The image of the Garut Regency Competitiveness Index map can be seen in Figure 2

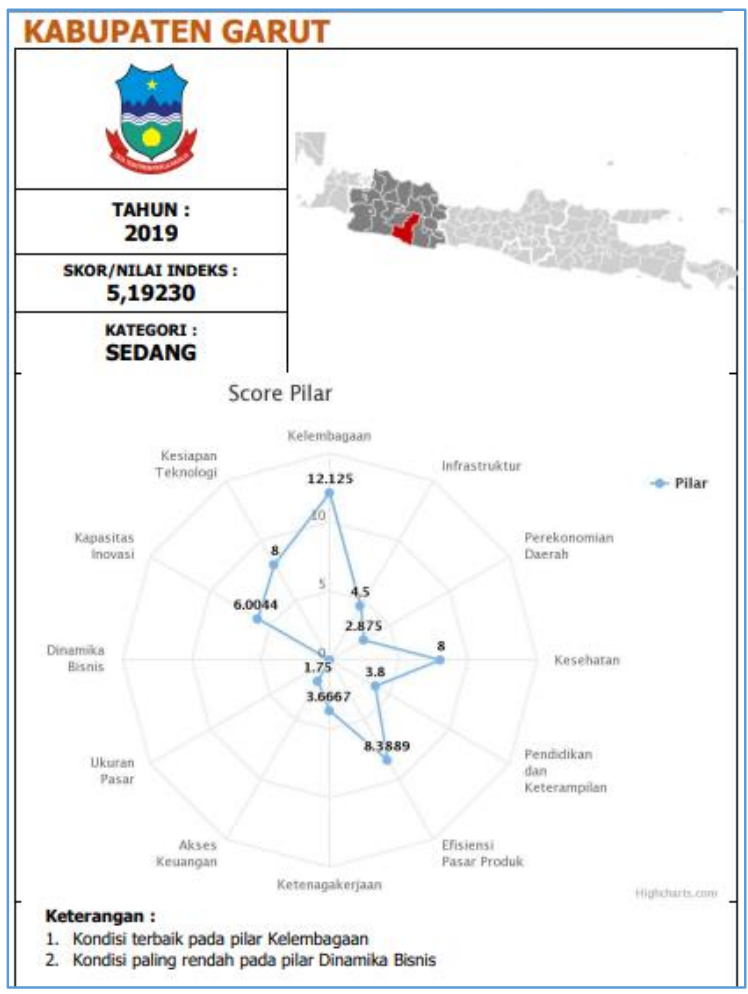

Figure 2. Garut Regency Competitiveness Index (Source: Directorate of Innovation System, 2019)

From the results of various researches conducted by Nurdianti, Prastawa, Budiawan in 2017, it is known that the supply chain has a significant positive influence on the performance of the organization, both financial and operational performance [7]. In addition, the application of the supply chain has a significant effect on competitive advantage. Furthermore, Santi, S. M. in 2019 in his research mentioned that supply chain management has a significant influence on the competitive advantages of MSMEs [8]. Then, the research conducted by Ilmiyati, Munawaroh, Munjiati in 2016 concluded that SCM practices in MSMEs have a significant influence on competitive advantage. Furthermore, competitive advantage can improve the company's performance [3]. The results of these three studies were supported by Hwihanus, Oscarius, and Rani (2021) in his research on "The role of supply chain management on Indonesian small and medium enterprise competitiveness and performance", which results in the conclusion that SCM has a significant effect on competitive toughness, competitive advantage can mediate the influence of SCM on organizational performance, and competitive advantage has a significant positive effect on organizational performance. The higher the competitive advantage occurs, the better the company's performance will be [9].

The researches that integrate the information technology in supply chain management and competitive advantage to improve MSME performance have not been widely conducted, especially for MSMEs in Garut Regency. Thus, this study aims to know: 1) the relationships and influences of information technology on supply chain management, 2) the relationships and influences of information technology and supply chain management partially on competitive advantage, 3) the influences of information technology and supply chain management simultaneously on competitive advantage, 4) the relationships and influences of competitive advantage on organizational performance, and 5) to explain the interactions that occur between information technology and supply chain management to competitive advantage and competitive advantage on organizational performance. Through this research, it is expected that MSMEs actors, especially in Garut Regency, empirically know and obtain information for efforts to increase competitiveness and maintain business.

\section{RESEARCH METHODS}

The approach used in this research is quantitative, while the research instrument used to collect research data is by spreading questionnaires that contain statements regarding indicators from information technology variables, supply chain management, competitive advantage, and organizational performance. The selection of answers on questionnaires is determined using the following Likert scales:

Disagree (TS):

Less agree $(\mathrm{KS})$ :

worth 1

Simply Agree (CS): $\quad$ worth 3

Agree (S):

worth 4

Strongly Agree (SS): $\quad$ worth 5

This type of data in this study is quantitative data sourced from the owner or person responsible for the MSMEs. The population of this study is MSMEs located in 
International Journal of Computer and Information System (IJCIS)

Peer Reviewed - International Journal

Vol : Vol. 03, Issue 01, January 2022

e-ISSN : 2745-9659

https://ijcis.net/index.php/ijcis/index

Garut Regency, while the sample used is 109 MSMEs engaged in the manufacture and sale of products, with the following characteristics: 1) Already involving information technology in its business processes, at least it has utilized social media, 2) Involving suppliers in the procurement of raw materials, and 3) Having resellers or other merchants who help the process of distributing products.

After the data is obtained, linear regression and Pearson product-moment correlation analysis technique is carried out and SPSS software is used that aims to find out whether there is a relationship between variables. Regression calculations are then performed to find out the magnitude of influence between information technology, supply chain management, competitive advantage, and organizational performance. The following is the research framework used:

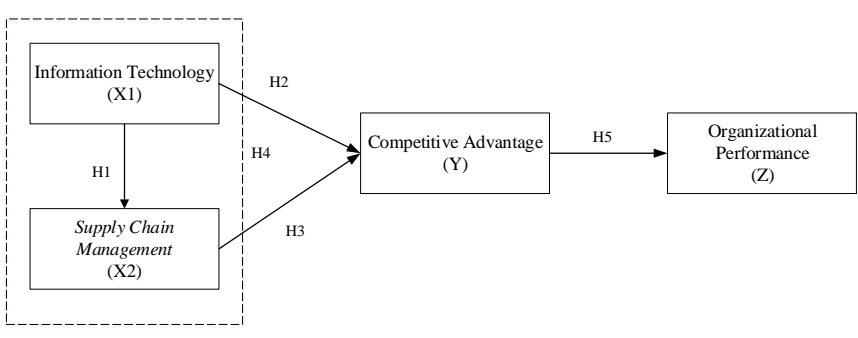

Figure 3. Research Framework

Based on figure 2, the hypothesis in this study consists of:

a. $\mathrm{H}_{1}$ : Information technology affects supply chain management.

b. $\mathrm{H}_{2}$ : Information technology affects competitive advantage.

c. $\mathrm{H}_{3}$ : Supply chain management influences competitive advantage.

d. $\mathrm{H}_{4}$ : Information technology and supply chain management simultaneously positively affect competitive advantage.

e. $\mathrm{H}_{5}$ : Competitive advantage positively affects organizational performance.

The structural equations in this study are as follows:

$\mathrm{X}_{2}=\mathrm{P}_{1} \cdot \mathrm{X}_{1}$

$\mathrm{Y}=\mathrm{P}_{2} \cdot \mathrm{X}_{1}+\mathrm{P}_{3} \cdot \mathrm{X}_{2}$

$\mathrm{Z}=\mathrm{P}_{4} . \mathrm{Y}$

Information: $\quad \mathrm{X}_{1} \quad=$ Information technology

$\mathrm{X}_{2} \quad=$ Supply chain management

$\mathrm{Y}=$ Competitive Advantage

$\mathrm{Z} \quad=$ Organizational Performance

$\mathrm{P}_{1} \quad=$ Path coefficient $\mathrm{X}_{1}$ to $\mathrm{X}_{2}$

$\mathrm{P}_{2} \quad=$ Path coefficient $\mathrm{X}_{1}$ to $\mathrm{Y}$

$\mathrm{P}_{3} \quad=$ Path coefficient $\mathrm{X}_{2}$ to $\mathrm{Y}$

$\mathrm{P}_{4} \quad=$ Path coefficient $\mathrm{Y}$ to $\mathrm{Z}$

The following is an operational definition of variables that serve as a reference in determining indicators for questionnaire statements at the time of data collection:

Table 1. Variable Operations

\begin{tabular}{|c|c|l|}
\hline No & Variable & \multicolumn{1}{c|}{ Sub Variables } \\
\hline 1 & $\begin{array}{l}\text { Information } \\
\text { Technology }\end{array}$ & $\begin{array}{l}\text { 1) Information } \\
\text { 2) Transaction }\end{array}$ \\
\hline
\end{tabular}

\begin{tabular}{|c|c|c|}
\hline No & Variable & Sub Variables \\
\hline & & $\begin{array}{l}\text { 3) Interaction and } \\
\text { customization }\end{array}$ \\
\hline 2 & $\begin{array}{l}\text { Supply Chain } \\
\text { Management }\end{array}$ & $\begin{array}{l}\text { 1) Supplier partnership } \\
\text { 2) Customer relationship } \\
\text { 3) Sharing information } \\
\text { 4) Information quality } \\
\text { 5) Postponement } \\
\text { 6) Warehousing management } \\
\text { 7) Forecasting }\end{array}$ \\
\hline 3 & $\begin{array}{l}\text { Competitive } \\
\text { Advantage }\end{array}$ & $\begin{array}{l}\text { 1) Price } \\
\text { 2) Delivery } \\
\text { 3) Product innovation } \\
\text { 4) Product quality } \\
\text { 5) Time to market }\end{array}$ \\
\hline 4 & $\begin{array}{l}\text { Organizational } \\
\text { Performance }\end{array}$ & $\begin{array}{l}\text { 1) Market Share } \\
\text { 2) Return of investment } \\
\text { 3) Sales growth } \\
\text { 4) Sales profit margin } \\
\text { 5) Production costs }\end{array}$ \\
\hline
\end{tabular}

\section{RESULT AND ANALYSIS}

Based on the analysis of correlation and regression with SPSS software, the following are the results and discussions of this study:

\subsection{Pearson Product-Moment Correlation}

Based on the results of data processing, the following is a discussion of correlation in this study:

Table 2. Correlation Analysis

\begin{tabular}{|c|c|c|c|c|c|}
\hline & & $\begin{array}{c}\text { Informatio } \\
\mathrm{n} \\
\text { Technolog } \\
\mathrm{y}\end{array}$ & $\begin{array}{c}\text { Supply } \\
\text { Chain } \\
\text { Manageme } \\
\text { nt }\end{array}$ & $\begin{array}{l}\text { Competiti } \\
\text { ve } \\
\text { Advantage }\end{array}$ & $\begin{array}{l}\text { Organization } \\
\text { al } \\
\text { Performance }\end{array}$ \\
\hline \multirow{3}{*}{$\begin{array}{l}\text { Informati } \\
\text { on } \\
\text { Technolo } \\
\text { gy }\end{array}$} & $\begin{array}{l}\text { Pearson } \\
\text { Correlation }\end{array}$ & 1 & $.610^{* *}$ & $.659^{* *}$ & $.603^{* *}$ \\
\hline & $\begin{array}{l}\text { Sig. (2- } \\
\text { tailed) }\end{array}$ & & .000 & .000 & .000 \\
\hline & $\mathrm{N}$ & 109 & 109 & 109 & 109 \\
\hline \multirow[t]{3}{*}{ SCM } & $\begin{array}{l}\text { Pearson } \\
\text { Correlation }\end{array}$ & $.610^{* *}$ & 1 & $.665^{* *}$ & \\
\hline & $\begin{array}{l}\text { Sig. (2- } \\
\text { tailed) }\end{array}$ & .000 & & .000 & .000 \\
\hline & $\mathrm{N}$ & 109 & 109 & 109 & 109 \\
\hline \multirow{3}{*}{$\begin{array}{l}\text { Competiti } \\
\text { ve } \\
\text { Advantag } \\
\mathrm{e}\end{array}$} & $\begin{array}{l}\text { Pearson } \\
\text { Correlation }\end{array}$ & $.659^{* *}$ & $.665^{* *}$ & 1 & $.621^{* *}$ \\
\hline & $\begin{array}{l}\text { Sig. (2- } \\
\text { tailed) }\end{array}$ & .000 & .000 & & .000 \\
\hline & $\mathrm{N}$ & 109 & 109 & 109 & 109 \\
\hline \multirow{3}{*}{$\begin{array}{l}\text { Organizat } \\
\text { ional } \\
\text { Performa } \\
\text { nce }\end{array}$} & $\begin{array}{l}\text { Pearson } \\
\text { Correlation }\end{array}$ & $.603^{* *}$ & $.543^{* *}$ & $.621^{* *}$ & 1 \\
\hline & $\begin{array}{l}\text { Sig. (2- } \\
\text { tailed) }\end{array}$ & .000 & .000 & .000 & \\
\hline & $\mathrm{N}$ & 109 & 109 & 109 & 109 \\
\hline
\end{tabular}

Based on table 2, it can be known that the correlation between information technology and supply chain management has a strong and unidirectional relationship of 0.610 . This means that if the utilization of information technology is high then supply chain management will also be high. The correlation between information technology and competitive advantage has a strong and unidirectional relationship that is 0.659 . Furthermore, it can be known that the correlation between information technology and organizational performance of 0.603 is expressed as a strong and unidirectional correlation. 
International Journal of Computer and Information System (IJCIS)

Peer Reviewed - International Journal

Vol : Vol. 03, Issue 01, January 2022

e-ISSN : 2745-9659

https://ijcis.net/index.php/ijcis/index

Then, the correlation between supply chain management and competitive advantage of 0.665 is expressed as strong and unidirectional. And the latter correlation between competitive advantage and organizational performance of 0.621 was declared strong and unidirectional. This means that the higher the competitive advantage, the higher the performance of the organization.

\subsection{Regression}

Based on the results of data processing, the following is a discussion of hypotheses in this study:

1) Information technology influences supply chain management $\left(\mathrm{H}_{1}\right)$

The following is the result of the t-test on structural equation 1 to test $\mathrm{H}_{1}$ :

Table 3. Test T Equation 1

\begin{tabular}{|c|c|c|c|c|c|c|c|}
\hline \multirow{2}{*}{ Model } & \multicolumn{2}{|c|}{$\begin{array}{c}\text { Unstandardized } \\
\text { Coefficients }\end{array}$} & $\begin{array}{c}\text { Standardized } \\
\text { Coefficients }\end{array}$ & \multirow{2}{*}{ T } & Sig. & \multirow{2}{*}{ R } & $\begin{array}{c}\text { R } \\
\text { Square }\end{array}$ \\
\cline { 2 - 5 } & $\mathbf{B}$ & $\begin{array}{c}\text { Std. } \\
\text { Error }\end{array}$ & Beta & & & & \\
\hline \multirow{2}{*}{1 (Constant) } & 10.952 & 3.254 & & 3.365 & .001 & & \\
\hline $\begin{array}{c}\text { Information } \\
\text { Technology }\end{array}$ & .540 & .068 & .610 & 7.966 & .000 & $.610^{\mathrm{a}}$ & .372 \\
\hline
\end{tabular}

The result of the analysis obtained the value $\mathrm{t}$ calculated $=$ $7,966>\mathrm{t}$ table $=1,982(\mathrm{df} 107$; sig. 0.05). While the probability of $0,000<0.05$, meaning that $\mathrm{H}_{1}$ in this study is accepted, namely information technology has a positive and significant effect on supply chain management of 0.610 or $61 \%$ (number R). While the path coefficient of 0.372 means that information technology contributes to supply chain management by $37.2 \%$, while the remaining $62.8 \%$ (100\%$37.2 \%$ ) is influenced by other variables outside this model. The results of this study were supported by Jumady Sinaga et al. in 2021 in their research which concluded that information and communication technology had a significant effect on supply chain management with a t-value of $6,879 \geq 1,967$ and $\mathrm{P}$-value $\leq 0.05$.

2) Information technology and supply chain management have a partial competitive advantage $\left(\mathrm{H}_{2}\right.$ and $\left.\mathrm{H}_{2}\right)$

The following is the result of the t-test in equation 2 to test $\mathrm{H}_{2}$ and $\mathrm{H}_{3}$ :

Table 4. Test T Equation 2

\begin{tabular}{|c|c|c|c|c|c|}
\hline \multirow{2}{*}{ Model } & \multicolumn{2}{|c|}{$\begin{array}{c}\text { Unstandardized } \\
\text { Coefficients }\end{array}$} & $\begin{array}{c}\text { Standardized } \\
\text { Coefficients }\end{array}$ & \multirow{2}{*}{ t } & \multirow{2}{*}{ Sig. } \\
\cline { 2 - 5 } & B & $\begin{array}{c}\text { Std. } \\
\text { Error }\end{array}$ & Beta & & \\
\hline $\begin{array}{l}\text { (Constant) } \\
\text { Information } \\
1\end{array}$ & 8.550 & 2.747 & & 3.113 & .002 \\
$\begin{array}{l}\text { Technology } \\
\begin{array}{l}\text { Supply Chain } \\
\text { Management }\end{array}\end{array}$ & .335 & .069 & .403 & 4.874 & .000 \\
\hline
\end{tabular}

a. Information Technology on Competitive Advantage $\left(\mathrm{H}_{2}\right)$ The results of the t-test indicate that $\mathrm{H} 2$ in this study is accepted, namely information technology has a positive and significant effect on competitive advantage because tcount $=4.874>$ t table $=1.982($ df 106; sig. 0.05) with a probability of $0.000<0.05$. The path coefficient of 0.403 means that the information technology has contribution to the competitive advantage which is $40.3 \%$ with a tvalue of 2.0581 .967 and a $\mathrm{P}$-value is 0.04 or 0.05 . The results of this study revealed that the information and communication technology have an effect on competitive advantage [2] [10].

b. Supply Chain Management to Competitive Advantage $\left(\mathrm{H}_{3}\right)$

The results of the t-test showed $\mathrm{H}_{3}$ in the study was accepted, meaning that SCM had a significant positive effect on competitive advantage because $t_{\text {count }}=5.073>$ $\mathrm{t}_{\text {table }}=1.982(\mathrm{df} 106 ;$ sig. 0.05$)$ with a probability of 0.000 $<0.05$. In this case, the path coefficient of 0.420 means that SCM contributes to the competitive advantage of $42 \%$. The results of this study were supported by [2] [11] [8] [12] in their research which concluded that the application of SCM had a significant effect on competitive advantage.

3) Information technology and supply chain management simultaneously have a positive effect on competitive advantage $\left(\mathrm{H}_{4}\right)$

The following is the result of the $\mathrm{f}$ test on structural equation 2 to test $\mathrm{H}_{4}$ :

Table 5. Test F Equation 2

\begin{tabular}{|ll|c|c|c|c|c|c|l|}
\hline Model & $\begin{array}{c}\text { Sum of } \\
\text { Squares }\end{array}$ & Df & $\begin{array}{c}\text { Mean } \\
\text { Square }\end{array}$ & F & Sig. & R & $\begin{array}{l}\text { R } \\
\text { Square }\end{array}$ \\
\hline & Regression & 1291.694 & 2 & 645.847 & 63.443 & $.738^{\mathrm{a}}$ & & \\
1 Residual & 1079.077 & 106 & 10.180 & & & .738 & .545 \\
& Total & 2370.771 & 108 & & & & & \\
\hline
\end{tabular}

The result of the $f$ test obtained the value $F_{\text {calculate }}=63.443>$ $\mathrm{F}_{\text {table }}=3.08(\mathrm{df} 2 ; 106)$ with a probability of $0.000<0.05$. So $\mathrm{H}_{4}$ in this study is accepted, meaning that information technology $\left(\mathrm{X}_{1}\right)$ and supply chain management $\left(\mathrm{X}_{2}\right)$ have a simultaneous effect on competitive advantage (Y) of $73.8 \%$ (R). The contributions given by variables $X_{1}$ and $X_{2}$ simultaneously to $\mathrm{Y}$ are 0.545 (R2) or $54.5 \%$. The remaining $45.5 \%(100 \%-54.5 \%)$ is affected by other variables outside of this model.

4) Competitive advantage has a positive effect on organizational performance $\left(\mathrm{H}_{5}\right)$

The following is the output of the t-test analysis in equation 3 to test $\mathrm{H}_{5}$ :

Table 6. Test T Equation 3

\begin{tabular}{|c|c|c|c|c|c|c|c|}
\hline \multirow{2}{*}{ Model } & \multicolumn{2}{|c|}{$\begin{array}{l}\text { Unstandardized } \\
\text { Coefficients }\end{array}$} & \multirow{2}{*}{$\begin{array}{c}\begin{array}{c}\text { Standardized } \\
\text { Coefficients }\end{array} \\
\text { Beta }\end{array}$} & \multirow{2}{*}{$\mathbf{t}$} & \multirow{2}{*}{ Sig. } & \multirow{2}{*}{$\mathbf{R}$} & \multirow{2}{*}{$\begin{array}{c}\mathbf{R} \\
\text { Square }\end{array}$} \\
\hline & B & $\begin{array}{l}\text { Std. } \\
\text { Error }\end{array}$ & & & & & \\
\hline (Constant) & 6.495 & 1.575 & & 4.124 & .000 & & \\
\hline $\begin{array}{l}1 \text { Competitive } \\
\text { advantage }\end{array}$ & .329 & .040 & .621 & 8.192 & .000 & .621 & .385 \\
\hline
\end{tabular}

Based on table 4 it is known that the value $t_{\text {calculate }}=8.192>$ $\mathrm{t}_{\text {table }}=1.982(\mathrm{df} 107 ;$ sig. 0.05$)$, while the probability of 0.000 $<0.05$, meaning that $\mathrm{H}_{5}$ in this study is accepted that competitive advantage has a significant positive effect on organizational performance of $62.1 \%$. While the path coefficient of 0.385 means that competitive advantage contributes to the organizational performance of $38.5 \%$, while the remaining $61.5 \%(100 \%-38.5 \%)$ is influenced by other variables outside this model. The results of this study are supported by [2], [11], [7], [8], and [3] in their research which states that competitive advantage has a significant effect on organizational performance.

\subsection{Discussion of Implications}

The implications of this study point to the interaction between information technology variables and supply chain 
International Journal of Computer and Information System (IJCIS)

Peer Reviewed - International Journal

Vol : Vol. 03, Issue 01, January 2022

e-ISSN : 2745-9659

https://ijcis.net/index.php/ijcis/index

management to competitive advantage, as well as a competitive advantage over organizational performance. Here is a discussion of the interactions that took place:

1) Information technology to supply chain management $\mathrm{X}_{2}=0.372 \mathrm{X}_{1}$

The equation has meaning to the change in the average variable supply chain management $\left(\mathrm{X}_{2}\right)$, for any changes in information technology variables $\left(\mathrm{X}_{1}\right)$ amount of one unit. Information technology regression coefficient $\left(\mathrm{X}_{1}\right) \quad 0.372$ states that each addition of 1 information technology value $\left(X_{1}\right)$, will cause supply chain management value $\left(X_{2}\right)$ to increase by 0.372 . The positive value coefficient means that there is a positive relationship between information technology and supply chain management, so the higher the application of information technology, the supply chain management will increase.

2) Information technology and supply chain management to competitive advantage

$\mathrm{Y}=0.403 \mathrm{X}_{1}+0.420 \mathrm{X}_{2}$

The equation states that the information technology regression coefficient $\left(\mathrm{X}_{1}\right)$ of 0.403 means that if other independent variables are fixed in value and information technology $\left(\mathrm{X}_{1}\right)$ has increased by $1 \%$, then the value of competitive advantage (Y) will increase by 0.403 . The higher the technology is used, the higher the competitive advantage will occur. While the regression coefficient of the variable $\operatorname{SCM}\left(\mathrm{X}_{2}\right)$ of 0.420 means that if other independent variables of fixed value and supply chain management $\left(\mathrm{X}_{2}\right)$ increase by $1 \%$, then the value of competitive advantage $(\mathrm{Y})$ will increase by 0.420 . So, the higher the supply chain management, the higher the competitive advantage obtained.
3) Competitive
Advantage over
Organizational

Performance

$\mathrm{Z}=0.385 \mathrm{Y}$

The coefficient of the competitive advantage (Y) of 0.385 means that each addition of 1 value of competitive advantage $(\mathrm{Y})$ will cause the performance value of the organization $(\mathrm{Z})$ to be more increasing to 0.385 . A positive value coefficient means that there is a positive relationship between competitive advantage and organizational performance, so the higher the competitive advantage it will improve organizational performance.

Based on the relationships that occur between variables, Garut Regency MSMEs can maximize the utilization of information technology and supply chain management to support competitive advantage, by doing the following points based on sub-variables and indicators used:

1) Utilizing information technology in creating the transaction process, so that customers get the convenience of choosing, ordering, and returning products. In addition to convenience, MSME actors must be able to guarantee the security of transaction and customer data. With an easy and secure transaction process, MSME actors can make deliveries by the demand, so that satisfaction is obtained from customers.

2) Interacting by involving customers in the product creation process, such as being willing to accept input or proposals desired by customers. That way, MSME actors can offer products according to the needs and desires of customers.
3) Using information technology to find out the development of competitors or competitors so that they can make future planning. That way, MSMEs can move faster in developing products compared to competitors and can be pioneers in introducing new products to the market.

4) Establishing good relationships and cooperation with suppliers, and including suppliers in product quality planning, MSMEs can obtain raw materials easily, cheaply, and get the expected quality. Thus, the dimensions of price and product quality on competitive advantage can be achieved. In addition, it can overcome the shortage of raw materials if at any time there is increased customer demand.

5) The use of information technology will make it easier for MSMEs to convey information about products to customers, know the desires of future customers who can create product innovation, and facilitate transactions made by customers. By providing good and easy service, it will be a plus for MSMEs.

6) Establishing good relationships and having quality information with business partners is also important to do because it can help MSMEs in distributing products to customers so that they can more quickly and easily reach the level of sales that have been targeted. In addition, the involvement of business partners or other traders will help MSMEs in conducting forecasting or forecasting processes that are useful to predict changes in the amount of market demand, raw material supplies, and budget allocation.

7) Utilizing information technology in recording the availability of raw materials and products in warehouses/stores, to regulate the production and delivery of products and order raw materials.

8) With the achievement of competitive advantage, the performance of the organization can increase due to the achievement of market growth targets, increased sales growth, achieving profits and return on capital following the target, and being able to achieve production costs as planned.

\section{CONCLUSION}

The following are the conclusions and suggestions of this study based on the results and discussions:

\subsection{Conclusion}

Based on the results of processing, analysis, and discussion of data, the conclusions in this study are:

1) Information technology has a strong and unidirectional relationship and has a positive effect on supply chain management by $61 \%$. The higher the utilization of information technology, the better supply chain management.

2) Information technology and supply chain management partially have a strong and unidirectional relationship and have a positive effect on competitive advantage, with variable influences of $40.3 \%$ and $42 \%$. The higher the utilization of information technology or the application of supply chain management in MSMEs, the higher the achievement of competitive advantage. 
International Journal of Computer and Information System (IJCIS)

Peer Reviewed - International Journal

Vol : Vol. 03, Issue 01, January 2022

e-ISSN : 2745-9659

https://ijcis.net/index.php/ijcis/index

3) Information technology and SCM simultaneously positively affected the competitive advantage of $73.8 \%$. The higher the utilization of information technology and the application of supply chain management simultaneously, the higher the achievement of competitive advantage.

4) Competitive advantage has a strong and unidirectional relationship and has a positive influence on the performance of MSMEs of Garut regency by $62.1 \%$. The higher the competitive advantage achieved, it will improve market and financial performance in MSMEs.

\subsection{Suggestion}

In future research, it is advisable to consider and use other variables that can support competitive advantage and organizational performance in MSMEs to the maximum. For business actors are advised to establish good cooperation with supply chain actors and government agencies or related agencies, to support business development and overcome some of the obstacles faced today. In addition, MSMEs must follow and utilize the development of information technology in their business processes.

As for government agencies that have responsibility for the development of business actors, it is expected to maximize the process of coaching, socializing, and training, providing facilities and capital or others as a whole, so that business actors, especially in Garut Regency, can grow and can face business competition easily and can maintain their business in the long term.

\section{THANK-YOU NOTE}

The author thanked all parties involved in the preparation of this study. Furthermore, to the Institute of Business Technology - AAS Indonesia and the International Journal of Computer \& Information System (IJCIS) who have facilitated the author in the publication of this research.

[1] A. N. S. A. H. N. Aditya Tri Wijaya, Optimalisasi Peran BMT Guna Meningkatkan Pemberdayaan Terhadap Usaha Mikro Kecil Menengah (UMKM) Dengan Metode Pendampingan Berbasis Comunication, Development, Controling( $C D C$ ). 2018.

[2] J. Sinaga, E. Anggraeni, and A. S. Slamet, "The Effect of Supply Chain Management Practices and Information and Communication Technology on Competitive Advantage and Firm Performance (Case Study: SMEs of Processed Food in Jakarta)," Indones. J. Bus. Entrep., vol. 7, no. 1, p. 91, 2021.

[3] A. Ilmiyati and M. Munawaroh, "Pengaruh manajemen rantai pasokan terhadap keunggulan kompetitif dan kinerja perusahaan (Studi pada usaha kecil dan menengah di Kabupaten Bantul)," $J$. Manaj. Bisnis, vol. 7, no. 2, pp. 226-251, 2016.

[4] R. Slamet, B. Nainggolan, R. Roessobiyatno, H. Ramdani, and A. Hendriyanto, "Strategi pengembangan UKM digital dalam menghadapi era pasar bebas," J. Manaj. Indones., vol. 16, no. 2, pp. 136-147, 2016.

[5] C. N. Aritonang, "Tranformasi Digital pada UMKM untuk Pemulihan Ekonomi Indonesia," vol. 21, no. 1, pp. 1-9, 2020.

[6] I. Firmansyah, W. D. Dermawan, A. H. Munawar, and D. A. Rahmani, "Meningkatkan Daya Saing UMKM di Era New Normal Melalui Pendekatan Analytic Network Process (ANP)," J. Ekon. Indones., vol. 10, no. 2, pp. 173-187, 2021.

[7] W. B. Andini Ratih Nurdianti , Heru Prastawa, “Analisa Pengaruh Praktek Manajemen Rantai Pasok terhadap Keunggulan Kompetitif dan Kinerja Organisasi pada UMKM Handycraft dan Tas di Semarang," Ind. Eng. Online J., vol. 6, no. 2, 2017.

[8] S. M. Santi, "Pengaruh Supply Chain Management $(\mathrm{Scm})$ Terhadap Keunggulan Bersaing Dan Kinerja Perusahaan Pada Ukm Industri Kuliner Kabupaten Sleman," 2019.

[9] H. Hwihanus, O. Y. A. Wijaya, and D. R. Nartasari, "The role of supply chain management on Indonesian small and medium enterprise competitiveness and performance," Uncertain Supply Chain Manag., vol. 10, no. 1, pp. 109-116, 2021, doi: 10.5267/j.uscm.2021.10.005.

[10] A. Ikhwana and M. K. Dewi, "Pengaruh Faktor Sosial, Pribadi, Harga, dan Desain Terhadap Keputusan Pembelian Batik Lokal Melalui Teknologi Informasi," Kalibrasi, vol. 18, no. 2, pp. 58-65, 2020, doi: doi.org/10.33364/kalibrasi/v.182.737 . 